\title{
公的自己意識が授業中の携带電話における迷惑行動に及ぼす影響
}

\author{
$\bigcirc$ 栗林克匡 \\ (北星学園大学社会福祉学部) \\ キーワード : 携帯電話、社会的迷惑、公的自己意識
}

The influence of public self-consciousness on inconsiderate cell-phone use in the classroom

\section{Yoshimasa KURIBAYASHI}

(School of Social Welfare, Hokusei Gakuen Univ.)

Key Words: cell-phone, social inconsiderate behavior, public self-consciousness

\section{目 的}

携帯電話の使用マナーに関する意識は多様であり、同じ公共空間 でも、場所によってマナ一意識に「合意のできている」ところと「合 意のできていない」ところがある(三上, 2001)。使用してはいけな いという合意のできている場所は、病院などの安全の配慮や静寂さ を保つ必要のある場所だという共通点があるが、合意のできていな い場所では、「電車やバスの中」「レストランの中」「職場で勤務中」 などが挙げられている。大学生にとって授業中の携帯電話使用も十 分な合意が得られているとはいいがたい。教室で大人数で行われる 授業は、匿名性が高く、互いに接近した状態で長時間居合わせ、被 害を回避できない場所といえよう。このような場所での迷惑行為の 抑制には個人差が存在すると考えられる。特に他者の目を強く意識 する公的自己意識が高い者は社会的迷惑行為を抑制すると考えら れる。本研究では、大学生の授業中の携帯電話使用の程度と、使用 に対する迷惑認知について公的自己意識を考慮しながら検討する。

\section{方 法}

調査対象者: 大学生 108 名（男性 33 名、女性 75 名）。平均年齢は 19.72 歳 $(\mathrm{SD}=0.88)$ であった。

質問紙の構成 :

(1)携帯電話の使用実態 : 所有歷、携帯の通話・メール・ゲームの 使用時間と頻度などを尋ねた。 (2)授業中の携帯電話の迷惑行動お よび迷惑認知 : 本調査の前に、大学生 45 名（男性 5 名、女性 40 名）に、授業中の携帯電話使用に関して「迷惑だと思うこと」「気 をつけていること」を自由記述で回答させた結果を参考に、20 項 目を授業中の携帯電話の迷惑行動・認知尺度として採用した。大学 の授業中の状況を記述した文章を読み(100 名ほどの出席者で、周 りに知っている人がいない状況）そそような状況下での自分自身 の迷惑行動の程度について、どの程度その行動をすると思うかを

「絶対しない(1)〜必ずする (4)」の 4 段階で評定させた。また同 20 項目を用い、迷惑の認知についてあなたがどの程度迷惑だと感 じるかということを「全く迷惑にならない(1)～非常に迷惑になる （7）」の 7 段階で評定させた。（3)公的自己意識 : 菅原(1984)の自 意識尺度から公的自己意識に関する 11 項目を 7 段階で回答させた。 結 果

まず迷惑行動の程度 20 項目について、主因子法プロマックス回 転による因子分析を行った結果、 7 因子が抽出された。第 1 因子は、

「10. マナーモードのバイブを鳴らす」「2.この授業中はサイレント マナーモードにする (音もバイブも鳴らない状態) (逆転項目)」「11. 机の上でマナーモードのバイブを鳴らす」「1.この授業中はマナー モードにする（音は鳴らない、バイブは鳴る状態）」の４項目で、

“バイブ鳴動” 因子とした。第 2 因子は、「4.この授業中にかかっ てきた着信には出る」「7. 着信があった場合、電話には出ずに授業 後にかけなおす (逆転項目)」「3.この授業中に通話をする」「6. 着信 があった場合、電話に出ながら退室する」の 4 項目で、“通話”因 子とした。第 3 因子は「13. 先生に見えないように携帯電話を使用 する」「14. 周囲の人に見えないように携帯電話を使用する」の 2 項 目で “隠れて使用” 因子とした。第 4 因子は、「16. 携帯電話内のゲ 一ムで友達と騒ぐ」「15. 授業中に携帯電話内のゲームで遊ぶ」の 2
項目で、“ゲーム遊び”因子とした。第 5 因子は、「8.この授業中に 着信音を鳴らす」「9.この授業中に音を鳴らす（アラーム音など着 信音以外)」の 2 項目で “着信音鳴動” 因子とした。第6因子は、

「18. 携帯電話の電源を切っておく」「19. 授業中は緊急時以外携帯 電話を使用しないようにする」の 2 項目で、“電源オフ”とした。 第 7 因子は、「17. 携帯電話を時計代わりとして使用する」の 1 項目 のみで、“時計代わり”因子とした。各因子を構成する項目 (因子負 荷量. 40 以上のもの)の平均值を以下の分析に用いた。なお、同 20 項目を用いて迷惑認知の評定も行ったが、迷惑行動の程度と対応さ せやすいように、そのまま同じ因子で迷惑認知得点も算出した。

次に迷惑行動の程度および迷惑認知の各因子得点を従属変数、公 的自己意識を独立変数とする 1 要因分散分析を行った (表 1 )。公的 自己意識は、平均值(54.95) を基に高群と低群に分けた。迷惑行動 の程度については、公的自己意識の高群が低群よりも、”隠れて使 用 $(\mathrm{F}(1,103)=4.06, \mathrm{p}<.05)$ ” ” 時計代わりの使用 $(\mathrm{F}(1,103)=3.27$, $\mathrm{p}<.10) ” の$ 得点が高かった。迷惑認知については、公的自己意識の 高群が低群よりも、”バイブ鳴動 $(F(1,103)=6.76, p<.05)$ ”” 通話 $(\mathrm{F}(1,103)=6.30, \mathrm{p}<.05)$ ” ”着信音鳴動 $(F(1,103)=3.21, \mathrm{p}<.10)$ ” の得点が高かった。また” 電源オフ $(\mathrm{F}(1,103)=4.77, \mathrm{p}<.05)$ ” の得 点は、高群の方が低群よりも低く、迷惑と思っていないようである。 考 察

大学生の授業中の携帯電話使用に関寸る迷惑行動を見ると、大っ ぴらな使用は控えていることが窅える。しかし完全に電源をオフに することは少なく、特に公的自己意識の高い者は、周囲の人の目を 気にしつつ、時計代わりの使用や隠れての使用をしているようであ る。迷惑認知に関しては、着信時の音や振動、話し声など騒音とな るような使用については迷惑であると感じやすいようである。興味 深いのは、公的自己意識の高い者は低い者よりも騒音がでる使用は 迷惑だと感じやすいのに、実際の自分の行動は高低群間で差異は見 られていない。隠れての使用については迷惑度をそれほど高く認知 していないが、そのような行動は、むしろ公的自己意識が高い者の 方が行っている。公的自己意識の高い人は、周囲の様子を窅い、迷 惑をかけない範囲で最大限、携帯電話を使用するといえよう。

\begin{tabular}{|c|c|c|c|c|c|c|c|}
\hline & \multicolumn{3}{|c|}{ 迷惑行動の程度 (4段階) } & \multicolumn{4}{|c|}{ 迷惑認知 (7段階) } \\
\hline & $\begin{array}{l}\text { 公的自己意識 } \\
\text { 低群 }\end{array}$ & $\begin{array}{c}\text { 公的自己意識 } \\
\text { 高群 }\end{array}$ & F值 & $\begin{array}{l}\text { 公的自己意識 } \\
\text { 低群 }\end{array}$ & $\begin{array}{c}\text { 公的自己意識 } \\
\text { 高群 }\end{array}$ & F値 & \\
\hline \multirow[t]{2}{*}{ バイブ鳴動因子 } & 2.00 & 2.06 & 0.11 & 4.73 & 5.26 & $6.76^{*}$ & \\
\hline & $(0.84)$ & $(0.90)$ & & $(1.01)$ & $(1.04)$ & & \\
\hline \multirow[t]{2}{*}{ 通話因子 } & 1.45 & 1.41 & 0.21 & 5.68 & 6.10 & $6.30^{*}$ & \\
\hline & $(0.46)$ & $(0.41)$ & & $(1.04)$ & $(0.69)$ & & \\
\hline \multirow[t]{2}{*}{ 隠れて使用因子 } & 2.52 & 2.80 & $4.06^{*}$ & 2.74 & 2.55 & 0.31 & \\
\hline & $(0.66)$ & $(0.70)$ & & $(1.80)$ & $(1.65)$ & & \\
\hline \multirow[t]{2}{*}{ ゲーム遊ひ因子 } & 1.57 & 1.69 & 1.06 & 4.30 & 4.41 & 0.17 & \\
\hline & $(0.60)$ & $(0.59)$ & & $(1.44)$ & $(1.39)$ & & \\
\hline \multirow[t]{2}{*}{ 着信音鳴動因子 } & 1.17 & 1.23 & 0.64 & 5.45 & 5.95 & $3.21+$ & \\
\hline & $(0.39)$ & $(0.36)$ & & (1.53) & $(1.30)$ & & \\
\hline \multirow[t]{2}{*}{ 電源オフ因子 } & 1.76 & 1.73 & 0.07 & 2.14 & 1.58 & $4.77^{*}$ & \\
\hline & $(0.60)$ & $(0.64)$ & & $(1.54)$ & $(1.06)$ & & \\
\hline \multirow{2}{*}{ 時計代わり因子 } & 2.98 & 3.28 & $3.27+$ & 2.23 & 1.85 & 1.70 & \\
\hline & $(0.90)$ & $(0.80)$ & & $(1.60)$ & (1.34) & & \\
\hline
\end{tabular}

本研究では新見真由さんの協力を得ました。記して感謝いたします。 